\title{
PECULIARITIES OF THE DOMESTIC COFFEE MARKET MICRO-SEGMENTATION
}

\author{
O. Holovan, O. Oliynyk, K. Serbinenko \\ Zaporizhzhia National University \\ M. Oliynyk \\ Taras Shevchenko National University of Kyiv
}

\begin{tabular}{l}
$\quad$ Key words: \\
Segmentation \\
Positioning \\
Coffee \\
Microsegmentation \\
Market niche \\
Survey \\
\hline
\end{tabular}

Article history:

Received 16.01.2017

Received in revised form

31.01.2017

Accepted 14.02.2017

Corresponding author:

O. Oliynyk

E-mail:

npnuht@ukr.net

\begin{abstract}
An approach to microsegmentation of the domestic coffee market has been proposed in the article. It involves the separation of consumers into groups, similar in their characteristics, using a number of criteria (geographic, psychological, behavioral). To achieve this goal, an array of initial data has been generated and identification of the necessary indicators, that are suitable for the microsegmentation process, has been carried out.

The coffee market research has revealed that geographic and demographic segmentation criteria are most commonly used in the $b 2 b$ sector due to the specifics of the product coffee that has been grown in certain areas, has special flavor coloration.

The analysis of primary data in sector b2c has found that, despite the rather low purchasing power of the population, there is an increase in the culture of coffee consumption: potential consumers prefer the highest quality beverage - natural coffee from selected grains of medium and higher average price segments.

The research has shown that coffee makers should pay particular attention to consumers who do not have the appropriate equipment for making natural coffee at home, but want to get a quality drink. The survey has indicated that more than one third of respondents have formed loyalty to certain coffee brands that are presented in the domestic market. Thus, domestic producers have a chance to find its niche.

The obtained results can be used by enterprises which are operating in this market to search for market niche and optimize marketing strategies in order to further improvement of the company's performance by increasing the competitiveness of the products offered in certain segments.

Prospects for further study are to determine the features of macrosegmentation of the coffee market and the development of the results of microsegmentation in the direction of quantitative analysis of the potential coffee market.
\end{abstract}

DOI: $10.24263 / 2225-2924-2017-24-1-11$ 


\section{ОСОБЛИВОСТІ МІКРОСЕГМЕНТАЦІЇ ВІТЧИЗНЯНОГО РИНКУ КАВИ}

\section{О.О. Головань, О.М. Олійник, К.Г. Сербіненко}

Запорізький національний університет

М.О. Олійник

Київський національний університет імені Тараса Шевченка

У статті запропоновано підхід до мікросегментування на вітчизняному ринку кави, що передбачає поділ споживачів на групи, спільні за свойми характеристиками, за допомогою низки критеріїв (географічних, психографічних, поведінкових). Для досягнення поставленої мети здійснено формування масиву вихідних даних та ідентифікацію необхідних показників, придатних для прочесу мікросегментаиії.

Дослідження ринку кави виявило, що у секторі b2b найбільш значимими є географічні та демографічні критерії сегментації, що обумовлено специфікою пропонованої продукиї - кави, що була вирощена у певній місиевості, має особливу смакову забарвленість.

Проведений аналіз первинних даних у секторі b2c виявив, що, незважсаючи на досить низьку купівельну спроможність населення, спостерігається підвищення культури споживання кави: потенційні споживачі віддають перевагу саме якісному напою - натуральній каві з відібраних зерен середнього та вище середнього иінових сегментів.

Дослідження показало, щчо виробники кави повинні звернути особливу увагу на споживачів, що не мають відповідного обладнання для приготування натуральної кави вдома, але бажають отримувати якісний напій. Опитування респондентів виявило, ще більше третини з них не мають сформованої прихильності та лояльності до певних брендів кави, представлених на вітчизняному ринку, тобто вітчизняні виробники мають шанс зайняти свою нішу.

Отримані результати можуть бути використані підприємствами, щьо діють на иьому ринку, для пошуку ринкової ніші та оптимізаиії стратегій маркетингу з метою подальшого підвищення ефективності роботи компаніі за рахунок зростання конкурентоспроможності пропонованої продукиї на визначених сегментах.

Перспективи подальшого дослідження полягають у визначенні особливостей макросегментаиії ринку кави та розвитку отриманих результатів мікросегментування в напрямку кількісного аналізу потениійного ринку кави.

Ключові слова: сегментація, позиціювання, кава, мікросегментування, ринкова німа, опитування.

Постановка проблеми. Вітчизняний ринок натуральної кави має високий потенціал. Однак він, поряд з іншими вітчизняними ринками, останнім часом зазнав значної трансформації під впливом зміни низки факторів. Серед основних факторів, що позитивно впливають на обсяги реалізації цієї продукції, слід відзначити розвиток культури споживання кави, а також відповідної інфраструктури ринку, розширення пропозиції доступних за ціною побутових кавамашин тощо. Проте досліджуваний ринок відчуває негативний вплив через скорочення 
планованих видатків поціновувачів кави на придбання цієї продукції, що обумовлено скороченням доходів, зменшенням пропозиції якісної доступної кави в зернах від країн-виробників через екологічні та природні проблеми тощо.

Серед основних дійових осіб ринку можна виокремити кінцевих споживачів кави (b2c), сектор HoReCa (b2b), посередників — торговельних агентів, що пропонують каву та чай різної якості в супермаркетах і торговельних центрах; компанії, які самостійно імпортують зерно кави та їі мікси з метою подальшої обробки та реалізації на ринку під власною торговельною маркою, інші гравці. Тож перспективи розвитку попиту на елітні сорти кави пов'язані не тільки зі зміною майнових характеристик споживачів, але й із формуванням відповідних потреб і переваг, що, у свою чергу, вимагає поглибленого вивчення поведінкових і психологічних характеристик споживачів елітного напою.

Аналіз останніх досліджень і публікацій. На сучасному етапі становлення вітчизняного товарного ринку актуалізуються дослідження, що допомагають його розвитку та ефективному функціонуванню. Серед таких досліджень одне 3 провідних місць посідає аналіз теоретичних і практичних аспектів сегментації. Питання сегментації на різних ринках досліджувались численними вітчизняними та зарубіжними дослідниками. Так, теоретичні засади методів і підходів до сегментування вивчались О.В. Куденко [1]. 3 практичної точки зору сегментацію розглядали Р.Р. Угнівенко [2], Ю.І. Гайда та Т.О. Сліпченко [3], які вивчали особливості продуктової та географічної сегментації на ринку банківських продуктів і послуг. В.Л. Кізима [4] розглядав сегментацію за сприйняттям вітчизняного туристичного продукту. На ринку швидкого харчування дослідження проводили Л.О. Попова, Т.Л. Мітяєва, А.В. Лозинська [5-6]; Т. Подвірна [7], Р. Дудяк та Р. Хірівський [8], Г. Заячковська [9] фокусувались на відмінностях процесу сегментації на світовому ринку. Проте дослідниками недостатньо уваги приділено вивченню аспектів мікросегментації на перспективному для подальшого розвитку ринку кави.

Метою статті $\epsilon$ визначення перспективних для подальшого розвитку вітчизняними виробниками сегментів ринку кави за рахунок його мікросегментування.

Для досягнення поставленої мети у статті було здійснено формування масиву вихідних даних та ідентифікацію необхідних показників, придатних для процесу сегментації. Отримані дані проаналізовано за допомогою методів економетрічного аналізу та багатомірного шкалування.

Викладення основних результатів дослідження. Методика сегментування ринку - це один 3 інструментів стратегічного маркетингового планування, який передбачає проведення маркетингових досліджень і виокремлення цільових споживачів, а також потенційні ринкові «вікна», де споживачі відчувають нестачу уваги з боку виробників та постачальників товарів і послуг. За допомогою цієї методики відбувається структурування ринку 3 використанням різноманітних критеріїв, які традиційно поділяються на географічні, демографічні, психографічні та поведінкові.

Різні за профілем компанії використовують для пошуку потенційних клієнтів комплексно диференційовані критерії сегментації. Так, на ринку b2b найвищу результативність виявляють географічні та демографічні критерії сегментації. Для вітчизняного ринку кави використання тих або інших критеріїв сегментації потребує подальшого дослідження. 
Використання географічних критеріїв сегментації актуалізується для ринку b2b за рахунок специфіки пропонованої на ньому продукції. Так, кава, що була вирощена в певній місцевості, має специфічну смакову забарвленість (рис. 1). Карта позиціонування за смаковими характеристиками була побудована за даними експертних дегустацій для таких країн-походження: Ефіопія, Кенія, Колумбія, Гватемала.

Для забезпечення конкурентоспроможної роботи на ринку b2c компанії повинні використовувати весь спектр критеріїв мікросегментації. Для визначення 3 практичної точки зору найефективніших 3 них було складено лист опитування, спрямований на цільову аудиторію міських мешканців, які споживають каву. В опитуванні взяло участь 70 осіб віком від 18 до 77 років. Переважну кількість складали (73\%) студенти вищих навчальних закладів віком від 18 до 24 років, які споживають каву щодня (71\%).

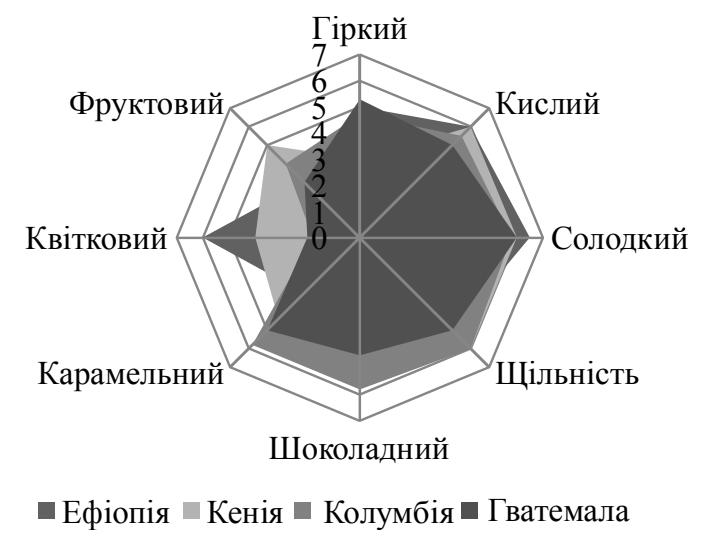

Рис. 1. Карта позиціонування кави за смаковими характеристиками

Респонденти зазначили, що кава для них - це смачний напій (38\%), який бадьорить (27\%), допомагає в спілкуванні (13\%) та є їхнім стилем життя (13\%) (рис. 2).

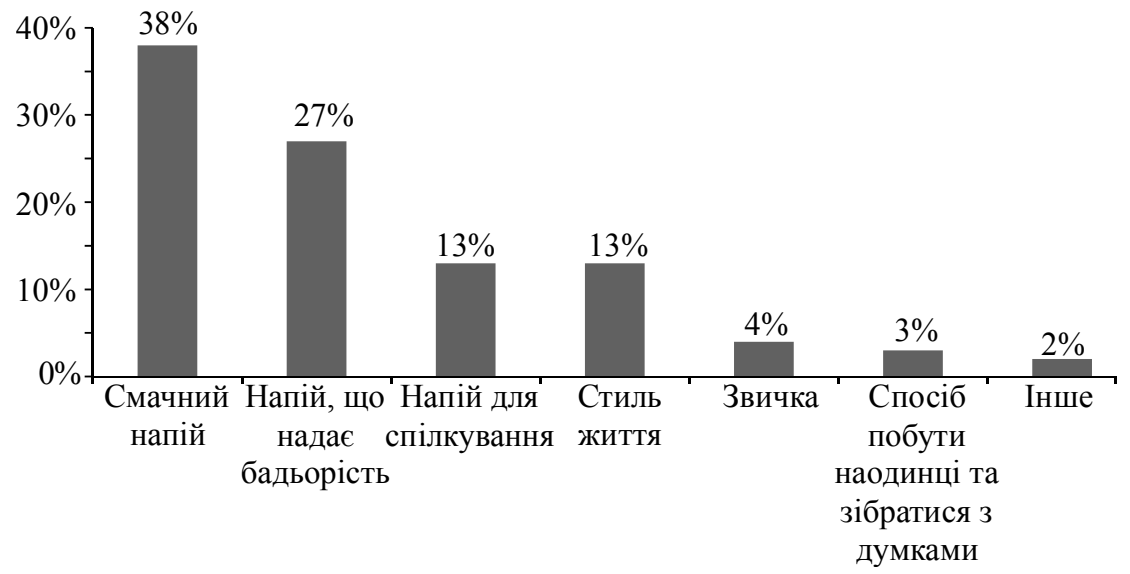

Рис. 2. Мотиви споживання кави, \% 
Обираючи каву, споживачі передусім звертають увагу на смак (34\%) та аромат (21\%), і тільки третє місце посідає співвідношення «ціна-якість» (16\%) (рис. 3).

Споживач, який стикнувся 3 неприємним смаком у подальшому відмовиться від купівлі неякісної продукції - відсутність неприємного післясмаку, який $\epsilon$ характерною ознакою неякісної кави, як важливий критерій обрання пропонованої продукції зазначили $12 \%$ респондентів (рис. 3 ).

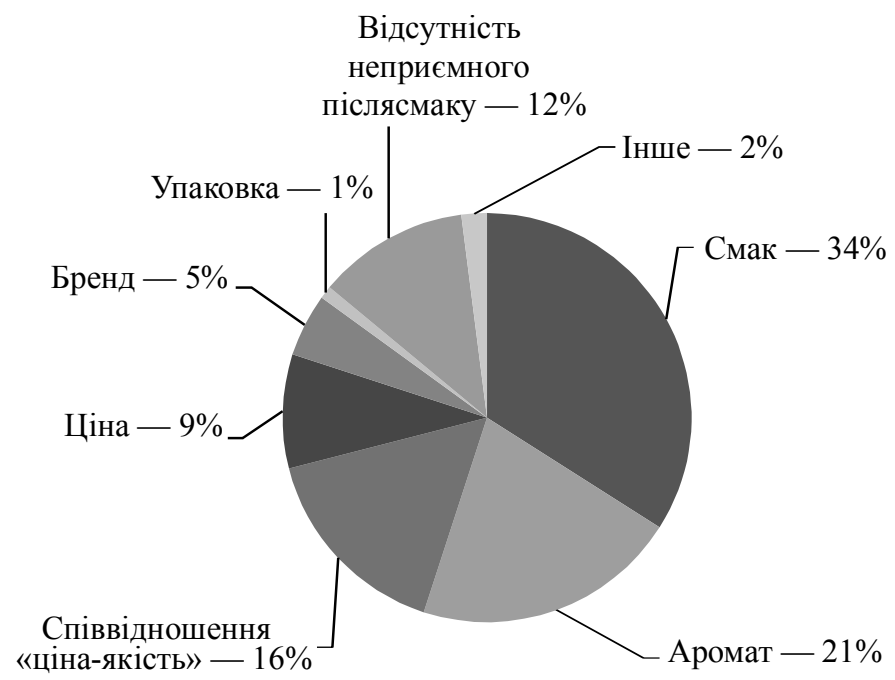

Рис. 3. Структура критеріїв обрання кави

Отже, більшість опитуваних позитивно вмотивовані до споживання саме смачного напою, що обумовлено визначеними вище психографічними та поведінковими критеріями сегментації, на які повинна звернути увагу фірмавиробник кави.

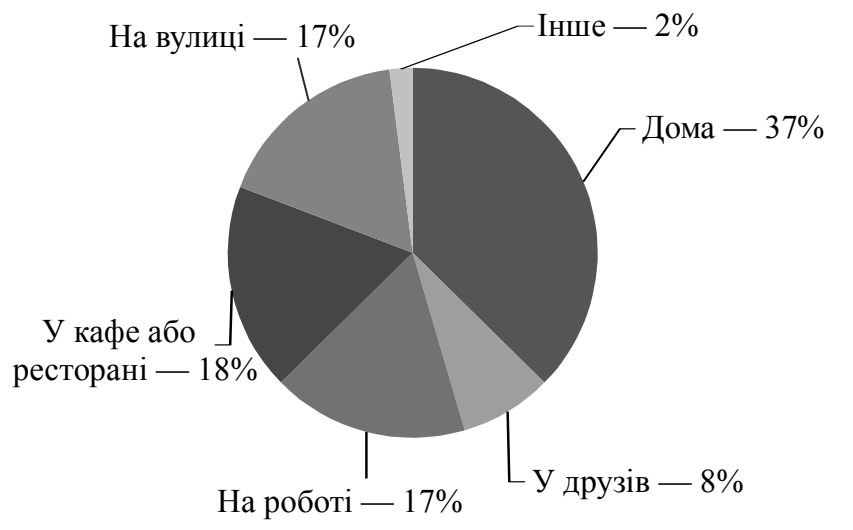

Рис. 4. Структура споживання кави за місцем споживання, \%

Дослідження виявило, що 45\% респондентів споживають каву в домашніх умовах: дома (37\%) та у друзів (8\%) (рис. 4). Наступним за популярністю 
місцем споживання кави $є$ сектор $\mathrm{HoReCa}$ - кафе та ресторани (18\%); рівними за частками є кава на винос і споживання в офісі (по 17\%). Отже, виробники кави повинні звернути особливу увагу на споживачів, що не мають відповідного обладнання для приготування натуральної кави вдома, але бажають отримувати якісний напій.

Проведене опитування виявило, що майже $35 \%$ споживачів не мають сформованої прихильності та лояльності до певних брендів кави, представленої на вітчизняному ринку, що $є$ потенційною нішою для виробників кави на цьому ринку.

Інші 65\% респондентів мають певні прихильності (рис. 5). Так, найбільшу кількість лояльних споживачів мають торговельні марки, які підтримуються на вітчизняному ринку відомими транснаціональними корпораціями LAVAZZA (28\%) та JACOBS (26\%). Це підтверджує ефективність їхньої стратегії глокального маркетингу та мікросегментації на локальному українському ринку.

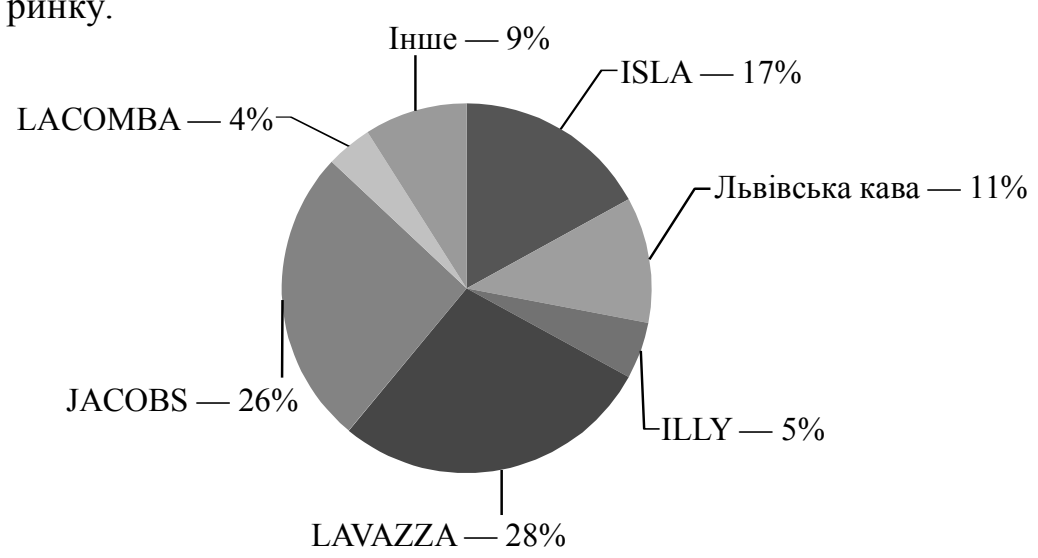

Рис. 5. Лояльність споживачів до брендів кави, наявних на вітчизняному ринку, \%

Вітчизняні торговельні марки ISLA та «Львівська кава» отримали прихильність $17 \%$ та $11 \%$ споживачів відповідно, що підкреслює важливість подальшої роботи з клієнтами їх служб маркетингу щодо формування лояльності до цих брендів.

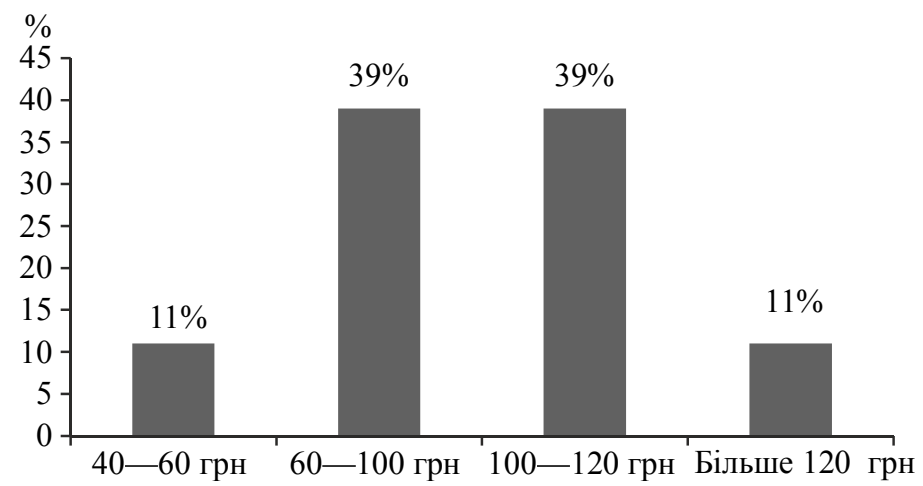

Рис. 6. Цінова сегментація ринку кави 
Як виявило дослідження, найбільш популярними ціновими сегментами $\epsilon$ сегмент 60-100 грн за пачку вагою 200 г та сегмент 100-120 грн за аналогічну пачку. Це підкреслює готовність споживачів купувати каву за достатньо високими цінами, враховуючи, що близько $11 \%$ готові віддати за напій більше 120 грн за пачку (рис. 6). При цьому рівень доходу споживачів, що брали участь в опитуванні, коливається в інтервалі від 3200 до 6000 грн на місяць (76\%).

Отже, вітчизняні виробники повинні враховувати, що споживачі готові купувати якісний напій, який можна приготувати вдома, від відомої торговельної марки за цінами вище за середні. Це і $є$ перспективна для розвитку ніші на ринку кави.

\section{Висновки}

Сегментація ринку є складним і багатоетапним процесом, що передбачає проведення макро- та мікросегментації. Пропоноване дослідження фокусується саме на мікросегментації, яка передбачає визначення іiі попередніх параметрів, саме поділ споживачів на групи та подальший вибір цільових сегментів і ринкових ніш.

На стадії мікросегментації вивчається обраний товарний ринок з метою 3'ясування основних характеристик його споживачів. На цій стадії необхідно обрати цільовий сегмент, більш докладно його проаналізувати за складом $\mathrm{i}$ особливостями реакції споживачів на стимули маркетингу.

Проведений аналіз первинних даних виявив, що вітчизняний ринок кави має такі характеристики: по-перше, незважаючи на досить низьку купівельну спроможність населення, спостерігається підвищення культури споживання кави. Так, потенційні споживачі віддають перевагу саме якісному напою натуральній каві з відібраних зерен середнього цінового сегменту. По-друге, майже третина споживачів не мають сформованих уподобань стосовно кавових брендів.

На основі проведених маркетингових досліджень та отриманої первинної інформації про споживачів було визначено потенційні ринкові «ніші», які необхідно зайняти вітчизняним виробникам кави, що планують збільшити ринкову частку та ефективність реалізації стратегій маркетингу за рахунок підвищення конкурентоспроможності пропонованої продукції.

Перспективи подальшого дослідження полягають у визначенні особливостей макросегментації ринку кави та розвитку отриманих результатів мікросегментування в напрямку кількісного аналізу потенційного ринку кави.

\section{Література}

1. Куденко O.B. Критичний аналіз методів та підходів до сегментування ринку / О.В. Куденко // Науковий вісник Херсонського державного університету. Серія Економічні науки. — Випуск 8. Частина 3. — 2014. — С. 79-82.

2. Угнівенко P.P. Продуктова та географічна сегментації ринку банківських продуктів і послуг в Україні / Р.Р. Угнівенко // Глобальні та національні проблеми економіки. Випуск 7. - 2015. - С. 757-762. 
3. Гайда Ю. I. Сегментація ринку стоматологічних послуг в Україні за географічним принципом / Ю.І. Гайда, Т.О. Сліпченко // Економічний аналіз: зб. наук. праць / Тернопільський національний економічний університет; редкол.: О.В. Ярощук (голов. ред.) та ін. - Тернопіль, 2017. - Том 27. — № 1. - С. 18-27.

4. Кізима В.Л. Сегментація ринку споживачів за сприйняттям вітчизняного туристичного продукту / В.Л. Кізима // Журнал науковий огляд. - 2015. — № 3(24). — С. 5-10.

5. Мітяєва Т.Л. Використання результативної сегментації для визначення потреб на ринку швидкого харчування / Т. Л. Мітяєва // Науковий вісник Полтавського університету економіки і торгівлі. - № 1(52). - 2012. - С. 179-183.

6. Попова Л.О. Особливості маркетингу на ринку продуктів швидкого приготування / Л.О. Попова, Т.Л. Мітяєва, А.В. Лозинська // Економічна стратегія і перспективи розвитку сфери торгівлі та послуг. - 2015. - Вип. 1. - С. 277-288 [Електронний ресурс]. Режим доступу : http://nbuv.gov.ua/UJRN/esprstp_2015_1_29.

7. Подвірна T. Маркетингова сегментація на світових ринках / Т. Подвірна // Галицький економічний вісник. — 2012. — № 6(39). — С.169-174.

8. Дудяк Р. Маркетингова сегментація світового ринку молокопродуктів / Р. Дудяк, Р. Хірівський // Аграрна економіка. - 2015. — Т. 8, № 3-4. - С. 44-51.

9. Заячковська Г. Критерії сегментування ринку міжнародних туристичних послуг / Г. Заячковська // Економічний аналіз. - 2011. - Вип. 9. - Ч. 3. - С. 115-118. 